\title{
Activity of Soil Urease, Phosphatase and Dehydrogenase as Influenced by Various Sources of Zinc in Rice (Oryza sativa L.)
}

\author{
M.R. Apoorva*, P. Chandrasekhar Rao, G. Padmaja and R. Subhash Reddy \\ Department of Soil science and Agricultural Chemistry, Professor Jayashankar Telangana \\ State Agricultural University, Rajendranagar, Hyderabad-500030, Telangana, India \\ *Corresponding author
}

\section{A B S T R A C T}

\begin{tabular}{|l|}
\hline K e y w o r d s \\
Nano zinc, Bio zinc, \\
Rice, Soil \\
application, \\
Enzymes
\end{tabular}

\section{Keywords}

Nano zinc, Bio zinc, application Enzymes

\section{Introduction}

Rice (Oryza sativa L.) is an important staple food crop among all the cereals. About $90 \%$ of rice grown and consumed in south and south East Asia. In some parts of the world consumption of rice is as high as $990 \mathrm{~g}$ per person per day (Sharma et al., 2015). India ranks first in the world in terms of area of rice cultivation with $44.6 \mathrm{~m}$ ha and second in productivity of $2.96 \mathrm{t} \mathrm{ha}^{-1}$.In Telangana state, rice is grown in an area of 17 lakh ha ${ }^{-1}$ with a production of 64 lakh metric tons with a productivity of $3.6 \mathrm{t} \mathrm{ha}^{-1}$ (India Stat., 20152016).

\begin{abstract}
A field experiment was conducted during kharif, 2015 at college farm, college of agriculture, Rajendranagar, Hyderabad to study the influence of various sources of zinc on soil enzyme activity. The experiment was laid out in Randomized Block Design with 12 treatments and 3 replications. The results of the experiments revealed that the highest urease activity at harvest was recorded in the treatment RDF+ Soil application of $\mathrm{ZnSO}_{4} @ 25 \mathrm{~kg} \mathrm{ha}^{-1}\left(370.3 \mu \mathrm{g} \mathrm{NH}_{4}{ }^{+}\right.$released $\mathrm{g}^{-1}$ soil $\left.2 \mathrm{hr}^{-1}\right)$, similarly in the acid and alkaline phosphatase activity highest value was seen in RDF+ Soil application of bio zinc@30 kg ha ${ }^{-1}\left(106.0,183.7 \mu \mathrm{g}\right.$ of $p$-nitrophenol g $\mathrm{g}^{-1}$ soil $\left.\mathrm{hr}^{-1}\right)$. The highest dehydrogenase activity was recorded in RDF+ Soil application of bio zinc@30 $\mathrm{kgha}^{-1}(84.8 \mu \mathrm{g}$ TPF produced $g$ soil d ${ }^{-1}$ ) which was on par with RDF+ Soil application of $\mathrm{ZnSO}_{4} @ 25 \mathrm{~kg} \mathrm{ha}^{-1}$ $\left(80.8 \mu \mathrm{g}\right.$ TPF produced $\mathrm{g}$ soil $\left.\mathrm{d}^{-1}\right)$. All the three enzyme activities were increased from the vegetative to panicle emergence stage and later showed decrease at harvest stage.
\end{abstract}

In India, zinc is considered as the fourth important yield limiting nutrient after nitrogen, phosphorus and potassium respectively. Zinc deficiency affects one third of the world's population.

In India, $47 \%$ of the soils are $\mathrm{Zn}$ deficient. Critical limit of a nutrient in soils refers to a level below which the crops will readily respond to its application. This critical limit varies with soil, crops and varieties. Critical limit of $\mathrm{Zn}$ for rice was $0.74 \pm 0.18 \mathrm{ppm}$ across the soils and indifferent agro-ecological regions of India (Muthukumararaja and Sriramachandrasekharan 2012). Hence, 
application of zinc fertilizers is essential in keeping sufficient amount of available zinc in soil solution, maintaining adequate zinc transport to seeds and for increases in the crop yield. Foliar or combined soil + foliar application of fertilizers under field conditions have proved to be highly effective and can be a practical way to maximize the zinc accumulation and uptake in grains.

Regarding the importance of $\mathrm{Zn}$, it is an essential element for all organisms. In its oxidized Zn (II) form, it acts as a catalytic or structural cofactor in a large number of enzymes and regulatory proteins (Maret 2009). Many plant processes are regulated by $\mathrm{Zn}$ containing enzymes such as $\mathrm{CO}_{2}$ fixation, maintenance of biological membranes, protein synthesis, auxin synthesis and formation of pollen grains. The efficiency of applied $\mathrm{ZnSO}_{4}$ is only 1 to $4 \%$ and most of the applied zinc is rendered unavailable to plants due to many factors such as leaching, fixation (Nair et al., 2010). Hence it is essential to minimize the nutrient losses in fertilizer application, increase the crop yield through the exploitation of new applications with the help of nano technology and nano meterials.

Nano fertilizers have unique physicochemical properties and the potential to boost the plant metabolism (Giraldo et al., 2014). The nano fertilizers or nano encapsulated nutrients might have the properties that are effective to crops, release the nutrients on demand, controlled release of chemical fertilizers that regulate the plant growth and enhanced target activity (DeRosa et al., 2010). Literally very little information exist on the application of nano zinc both in chemical and bioforms applied to soil and foliar application of these materials on rice crop under field conditions. Considering the deficiency status of $\mathrm{Zn}$ in soil and its importance, an attempt has been made to evaluate the effects of various methods of $\mathrm{Zn}$ application on key enzymes in soil.

\section{Materials and Methods}

A field experiment was conducted during kharif, 2015 at College Farm, College of Agriculture, PJTSAU. Experiment was laid out in Randomized Block Design with 12 treatments and 3 replications. The rice variety used was MTU-1010. The treatments were viz., T1-Control(no fertilizers were applied), T2- RDF@ N, $\mathrm{P}_{2} \mathrm{O}_{5}, \mathrm{~K}_{2} \mathrm{O} @ 120: 60: 40 \mathrm{~kg} \mathrm{ha}^{-1}$, T3-RDF+Soil application of $\mathrm{ZnSO}_{4} @ 25 \mathrm{kgha}^{-1}$ at transplanting, T4 and T5- RDF +Soil application of nano Zn @ $10 \mathrm{~kg} \mathrm{ha}^{-1}$ and $15 \mathrm{~kg}$ $\mathrm{ha}^{-1}$, T6 and T7- RDF +Soil application of bio Zn@15 kg ha ${ }^{-1}$ and $30 \mathrm{~kg} \mathrm{ha}^{-1}$ at transplanting, T8-RDF +foliar application of $0.2 \%$ as $\mathrm{ZnSO}_{4}$ at tillering and panicle emergence stage, T9 and T10-RDF + foliar application of $1 \mathrm{ml} \mathrm{l}^{-1}$ and $2 \mathrm{ml} \mathrm{l}^{-1}$ as nano zinc at tillering and panicle emergence stage, T11 and T12 -RDF +foliar application of $1.5 \mathrm{ml} \mathrm{l}^{-1}$ and $3 \mathrm{ml} \mathrm{l}^{-1}$ as bio zinc at tillering and panicle emergence stage. The study was taken up on a Vertisol $\left(\mathrm{pH} 8.24, \mathrm{EC}: 0.74 \mathrm{dSm}^{-1}\right)$, low in organic carbon $(0.42 \%)$, low in Nitrogen $\left(242 \mathrm{~kg} \mathrm{ha}^{-1}\right)$, high in available Phosphorus (92 $\mathrm{kg} \mathrm{P}_{2} \mathrm{O}_{5} \mathrm{ha}^{-1}$ ) and high in available Potassium $\left(376 \mathrm{~kg} \mathrm{~K}_{2} \mathrm{O}\right.$ $\left.\mathrm{ha}^{-1}\right)$. The DTPA extractable zinc was 0.3 $\mathrm{mgkg}^{-1}$.

\section{Application of fertilizers}

The products i.e., nano zinc and bio zinc formulations were obtained from M/S. Prathishta industries, Alwal, Secunderabad. These are being manufactured by the firm. The nano zinc soil and foliar formulation had $\mathrm{Zn}$ content of $40 \mathrm{mg} \mathrm{kg}^{-1}$ and bio zinc soil and foliar formulation contains $3 \% \mathrm{Zn}$. Along with $16 \%$ organic carbon.

\section{Assay of enzyme activity in soil}

Soil samples of each treatmental plot were collected at tillering stage, panicle initiation, seed filling and at harvest stage, and were immediately stored in polythene bags. The 
soils were preserved and stored at $5^{\circ} \mathrm{C}$ in a utilized for the assay of soil enzyme activity. refrigerator until analysis. These samples were

Methods employed for determination enzyme activity in soil

\begin{tabular}{l} 
Enzayme \\
Urease \\
\hline Acid \& Alkaline \\
Phosphatase \\
\hline Dehydrogenase \\
\hline
\end{tabular}
Method employed Tabatabai and Bremner (1972) $\mu \mathrm{g}$ of $\mathrm{NH}^{+4}$ released $\mathrm{g}^{-1} 2 \mathrm{~h}^{-1}$

Tabatabai and Bremner (1969) p-nitrophenol released $\mathrm{g}^{-1}$ soil $^{-1}$ Cassida et al., (1964). $\mu \mathrm{g}$ of TPF $\mathrm{g}^{-1}$ soil day $^{-1}$

The recorded data were subjected to statistical analysis using the analysis of variance technique for randomized block design as suggested by Panse and Sukhame (1978).

\section{Results and Discussion}

The results obtained from the present investigation on soil enzyme activity is presented in the following heads.

\section{Urease activity}

Soil urease plays a major role in catalysis of the hydrolysis of urea to ammonical form, which will be subsequently oxidized by nitrifiers to nitrate form, which increases the utilization rate of nitrogen fertilizer. Effect of different sources of zinc on the activity of soil urease $\left(\mu \mathrm{g} \mathrm{NH}{ }_{4}^{+}\right.$released $\mathrm{g}^{-1}$ soil $\left.2 \mathrm{hr}^{-1}\right)$ at different growth stages are presented in Table 1. The urease activity showed an increasing trend with the age of the crop. It increased from tillering stage to panicle emergence stage, exhibited highest activity at panicle emergence stage and there after the activity decreased at maturity. Similar results were reported by Senthil Kumar et al., (2000) at different growth stages of rice.

At 30DAT the highest urease activity was observed in the treatment receiving RDF+ Soil application of biozinc@30 kg ha ${ }^{-1}$ (395 $\mu \mathrm{g}$ $\mathrm{NH}_{4}{ }^{+}$released g ${ }^{-1}$ soil $2 \mathrm{hr}^{-1}$ ) which was on par with RDF+ Soil application of $\mathrm{ZnSO}_{4} @ 25 \mathrm{~kg}$ ha $^{-1}$ (389.6 $\mu \mathrm{g} \mathrm{NH}_{4}{ }^{+}$released $\mathrm{g}^{-1}$ soil $2 \mathrm{hr}^{-1}$ ). The lowest urease activity was observed in control $\left(136.0 \mu \mathrm{g} \mathrm{NH}_{4}{ }^{+}\right.$released g ${ }^{-1}$ soil $\left.2 \mathrm{hr}^{-1}\right)$ which was followed by $\mathrm{RDF}+$ foliar application of $0.2 \%$ zinc as $\mathrm{ZnSO}_{4}(169.3 \mu \mathrm{g}$ $\mathrm{NH}_{4}{ }^{+}$released g ${ }^{-1}$ soil $2 \mathrm{hr}^{-1}$ ) which was on par with $\mathrm{RDF}+$ foliar spray of $1 \mathrm{ml}^{-1}$ as nano zinc $\left(171.0 \mu \mathrm{g} \mathrm{NH}_{4}^{+}\right.$released $\mathrm{g}^{-1}$ soil $\left.2 \mathrm{hr}^{-1}\right)$.

At 60DAT there was a maximum increase in urease activity and the treatment receiving RDF+ Soil application of biozinc@30 kg ha ${ }^{-1}$ recorded the highest activity $\left(419.3 \mu \mathrm{g} \mathrm{NH}_{4}{ }^{+}\right.$ released $\mathrm{g}^{-1}$ soil $2 \mathrm{hr}^{-1}$ ) which was on par with $\mathrm{RDF}+$ Soil application of $\mathrm{ZnSO}_{4} @ 25 \mathrm{~kg} \mathrm{ha}^{-1}$ (406.0 $\mathrm{g} \mathrm{NH}_{4}{ }^{+}$released g ${ }^{-1}$ soil $2 \mathrm{hr}^{-1}$ ), RDF+ Soil application of bio zinc@ $15 \mathrm{~kg} \mathrm{ha}^{-1}$ (389.6 $\mu \mathrm{g} \mathrm{NH}_{4}^{+}$released $\mathrm{g}^{-1}$ soil $2 \mathrm{hr}^{-1}$ ). At harvest there was a decrease in urease activity among all the treatments and the highest value was seen in RDF+ Soil application of $\mathrm{ZnSO}_{4} @ 25$ $\mathrm{kg} \mathrm{ha}^{-1}\left(370.3 \mu \mathrm{g} \mathrm{NH}_{4}^{+}\right.$released ${ }^{-1}$ soil $\left.2 \mathrm{hr}^{-1}\right)$. The lowest was recorded in control $(93.48 \mu \mathrm{g}$ $\mathrm{NH}_{4}{ }^{+}$released $\mathrm{g}^{-1}$ soil $\left.2 \mathrm{hr}^{-1}\right)$. Similar results were also reported by Ramlakshmi (2011) at different growth stages of rice.

\section{Acid and alkaline phosphatase activity}

Phosphatases are broad groups of enzymes that are capable of catalyzing hydrolysis of esters and anhydrides of phosphoric acid. In soil ecosystems, these enzymes are believed to play critical roles in P cycles (Speir and Ross, 
1978) as evidence shows that they are correlated to $\mathrm{P}$ stress and plant growth. The effect of different sources of zinc on the activity of acid and alkaline phosphatase $(\mu \mathrm{g}$ of $p$-nitrophenol $\mathrm{g}^{-1}$ soil $\mathrm{hr}^{-1}$ ) is presented in Table 2.

\section{Acid phosphatase activity}

At 30DAT the highest acid phosphatase activity was observed in the treatment receiving RDF+ Soil application of biozinc@30 kg ha ${ }^{-1}(135.2 \mu \mathrm{g}$ of $p$-nitrophenol $\mathrm{g}^{-1}$ soil $\mathrm{hr}^{-1}$ ) which was on par with RDF+ Soil application of $\mathrm{ZnSO}_{4} @ 25 \mathrm{~kg} \mathrm{ha}^{-1}(129.8 \mu \mathrm{g}$ of $p$-nitrophenol $\mathrm{g}^{-1}$ soil $\mathrm{hr}^{-1}$ ).

The lowest acid phosphatase activity was observed in control (72.3 $\mu \mathrm{g}$ of $p$-nitrophenol $\mathrm{g}^{-1}$ soil $\mathrm{hr}^{-1}$ ) which was on par with $\mathrm{RDF}+$ foliar application of $0.2 \% \mathrm{ZnSO}_{4}$ spray $(72.3$ $\mu \mathrm{g}$ of $p$-nitrophenol $\mathrm{g}^{-1}$ soil $\mathrm{hr}^{-1}$ ).

Table.1 Effect of various sources of zinc on soil urease activity $\left(\mu \mathrm{g}\right.$ of $\mathrm{NH}^{+4} \mathrm{~g}^{-1}$ soil $2 \mathrm{~h}^{-1}$ )

\begin{tabular}{|c|c|c|c|c|c|}
\hline S. No & Treatment & $\begin{array}{l}\text { 30DAT } \\
\text { Tillering } \\
\text { stage }\end{array}$ & $\begin{array}{l}\text { 60DAT } \\
\text { Panicle } \\
\text { emergence } \\
\text { stage }\end{array}$ & $\begin{array}{l}\text { 90DAT } \\
\text { Grain filling } \\
\text { stage }\end{array}$ & Harvest \\
\hline T1 & Control (no fertilizers were applied) & 136.0 & 187.3 & 145.3 & 93.4 \\
\hline T2 & $\begin{array}{l}\text { Recommended dose of } \mathrm{N}: \mathrm{P}_{2} \mathrm{O}_{5}: \mathrm{K}_{2} \mathrm{O} \\
\text { @120:60:40 Kg ha }\end{array}$ & 286.0 & 309.2 & 282.8 & 258.0 \\
\hline T3 & $\begin{array}{l}\text { RDF +Soil application of } \mathrm{ZnSO4} \\
\text { @ } 25 \mathrm{Kg} \mathrm{ha}^{-1} \text { at transplanting }\end{array}$ & 389.6 & 406.0 & 393.9 & 370.3 \\
\hline T4 & $\begin{array}{l}\text { RDF + Soil application of nano zinc } \\
\text { as impregnated granules @ } 10 \mathrm{~kg} \\
\text { ha }^{-1} \text { at transplanting }\end{array}$ & 296.0 & 326.3 & 294.0 & 239.0 \\
\hline T5 & $\begin{array}{l}\text { RDF + Soil application of nano zinc } \\
\text { as impregnated granules @ } 15 \mathrm{~kg} \\
\text { ha }^{-1} \text { at transplanting }\end{array}$ & 324.3 & 365.5 & 265.8 & 209.1 \\
\hline T6 & $\begin{array}{l}\text { RDF +Soil application of bio zinc } \\
\text { @ } 15 \mathrm{~kg} \mathrm{ha}^{-1} \text { at transplanting }\end{array}$ & 338.9 & 389.6 & 333.9 & 300.8 \\
\hline T7 & $\begin{array}{l}\text { RDF + Soil application of bio zinc } \\
\text { @30 } \mathrm{kg} \mathrm{ha}^{-1} \text { at transplanting. }\end{array}$ & 395.0 & 419.3 & 369.7 & 321.0 \\
\hline T8 & $\begin{array}{l}\mathrm{RDF}+\text { Foliar spray of } 0.2 \% \text { as } \\
\mathrm{ZnSO}_{4}\end{array}$ & 169.3 & 216.0 & 177.6 & 121.9 \\
\hline T9 & $\begin{array}{l}\text { RDF +Foliar spray of } 1 \mathrm{ml} \mathrm{l}^{-1} \text { as } \\
\text { nano zinc }\end{array}$ & 171.0 & 252.1 & 213.0 & 162.5 \\
\hline T10 & $\begin{array}{l}\text { RDF +Foliar spray of } 2 \mathrm{ml} \mathrm{l}^{-1} \text { as } \\
\text { nano zinc }\end{array}$ & 211.0 & 272.0 & 215.7 & 197.8 \\
\hline T11 & $\begin{array}{l}\text { RDF +Foliar spray of } 1.5 \mathrm{ml} \mathrm{l}^{-1} \text { as } \\
\text { bio zinc }\end{array}$ & 227.8 & 282.6 & 256.8 & 198.9 \\
\hline \multirow[t]{3}{*}{ T12 } & $\begin{array}{l}\text { RDF +Foliar spray of } 3 \mathrm{ml} \mathrm{l}^{-1} \text { as bio } \\
\text { zinc }\end{array}$ & 229.6 & 300.6 & 276.6 & 204.7 \\
\hline & $\mathrm{SE}(\mathrm{m}) \pm$ & 16.9 & 17.2 & 16.4 & 12.6 \\
\hline & $\mathrm{CD}(\mathrm{P}=\mathbf{0 . 0 5})$ & 50.1 & 51.0 & 48.4 & 37.3 \\
\hline
\end{tabular}


Table.2 Effect of various sources of zinc on Acid and Alkaline phosphatase activity in soil ( $\mu \mathrm{g}$ of $P$ - Nitrophenol $\mathrm{g} \mathrm{soil}^{-1} \mathrm{~h}^{-1}$ )

\begin{tabular}{|c|c|c|c|c|c|c|c|c|c|}
\hline \multirow[t]{2}{*}{$\begin{array}{l}\text { S. } \\
\text { No }\end{array}$} & \multirow[t]{2}{*}{ Treatment } & \multicolumn{4}{|c|}{$\begin{array}{l}\text { Acid phosphatase activity } \\
\left(\mu \mathrm{g} \text { of } P \text { - Nitrophenol } \text { g Soil }^{-1} h^{-1}\right)\end{array}$} & \multicolumn{4}{|c|}{$\begin{array}{l}\text { Alkaline phosphatase activity } \\
\left(\mu \mathrm{g} \text { of } P \text { - Nitrophenol g Soil }{ }^{-1} \mathbf{h}^{-1}\right)\end{array}$} \\
\hline & & $\begin{array}{l}\text { 30 } \\
\text { DAT }\end{array}$ & $\begin{array}{l}\text { 60 } \\
\text { DAT }\end{array}$ & $\begin{array}{l}90 \\
\text { DAT }\end{array}$ & $\begin{array}{l}\text { Harve } \\
\text { st }\end{array}$ & $\begin{array}{l}\text { 30 } \\
\text { DAT }\end{array}$ & $\begin{array}{l}\text { 60 } \\
\text { DAT }\end{array}$ & $\begin{array}{l}90 \\
\text { DAT }\end{array}$ & $\begin{array}{l}\text { Harve } \\
\text { st }\end{array}$ \\
\hline T1 & $\begin{array}{l}\text { Control (no fertilizers } \\
\text { were applied) }\end{array}$ & 72.3 & 97.6 & 70.0 & 65.9 & 87.0 & 151.0 & 102.9 & 68.7 \\
\hline $\mathrm{T} 2$ & $\begin{array}{l}\text { Recommended dose of } \\
\mathrm{N}: \mathrm{P}_{2} \mathrm{O}_{5}: \mathrm{K}_{2} \mathrm{O} \\
@ 1120: 60: 40 \mathrm{Kg} \mathrm{ha}^{-1}\end{array}$ & 90.4 & 122.8 & 100.8 & 83.9 & 140.4 & 190.6 & 160.9 & 101.8 \\
\hline $\mathrm{T} 3$ & $\begin{array}{l}\text { RDF +Soil application } \\
\text { of ZnSO4@25Kg ha } \\
\text { at transplanting }\end{array}$ & 129.8 & 141.3 & 130.9 & 98.8 & 190.0 & 221.1 & 200.0 & 178.0 \\
\hline $\mathrm{T4}$ & $\begin{array}{l}\text { RDF + Soil application } \\
\text { of nano zinc as } \\
\text { impregnated granules } \\
\text { @ 10kg ha }{ }^{-1} \text { at } \\
\text { transplanting }\end{array}$ & 96.7 & 128.0 & 109.0 & 90.9 & 148.7 & 198.0 & 167.0 & 105.1 \\
\hline $\mathrm{T5}$ & $\begin{array}{l}\text { RDF + Soil application } \\
\text { of nano zinc as } \\
\text { impregnated granules } \\
\text { @ 15kg ha }{ }^{-1} \text { at } \\
\text { transplanting }\end{array}$ & 107.9 & 130.7 & 114.0 & 90.8 & 176.0 & 197.0 & 180.6 & 150.0 \\
\hline T6 & $\begin{array}{l}\text { RDF +Soil application } \\
\text { of bio zinc @ } 15 \mathrm{~kg} \mathrm{ha}^{-1} \\
\text { at transplanting }\end{array}$ & 109.0 & 139.0 & 125.1 & 96.8 & 187.4 & 201.6 & 190.5 & 164.6 \\
\hline $\mathrm{T7}$ & $\begin{array}{l}\text { RDF +Soil application } \\
\text { of bio zinc @ } 30 \mathrm{~kg} \mathrm{ha}^{-1} \\
\text { at transplanting. }\end{array}$ & 135.2 & 167.0 & 149.0 & 106.0 & 206.1 & 245.0 & 219.0 & 183.7 \\
\hline $\mathrm{T} 8$ & $\begin{array}{l}\text { RDF +Foliar spray of } \\
0.2 \% \text { as } \mathrm{ZnSO}_{4}\end{array}$ & 72.3 & 97.9 & 70.0 & 65.9 & 90.0 & 156.9 & 112.1 & 81.4 \\
\hline T9 & $\begin{array}{l}\text { RDF +Foliar spray of } \\
1 \mathrm{ml} \mathrm{l}^{-1} \text { as nano zinc }\end{array}$ & 106.0 & 130.9 & 114.0 & 90.8 & 94.9 & 165.0 & 123.0 & 83.8 \\
\hline T10 & $\begin{array}{l}\text { RDF +Foliar spray of } \\
2 \mathrm{ml} \mathrm{I}^{-1} \text { as nano zinc }\end{array}$ & 84.0 & 114.9 & 85.9 & 74.8 & 109.0 & 170.9 & 139.2 & 94.1 \\
\hline T11 & $\begin{array}{l}\text { RDF +Foliar spray of } \\
1.5 \mathrm{ml} \mathrm{I}^{-1} \text { as bio zinc }\end{array}$ & 88.6 & 118.0 & 93.3 & 76.9 & 120.0 & 180.9 & 141.0 & 97.0 \\
\hline T12 & $\begin{array}{l}\text { RDF + Foliar spray of } \\
3 \mathrm{ml} \mathrm{l}^{-1} \text { as bio zinc }\end{array}$ & 90.0 & 121.0 & 98.8 & 81.0 & 123.0 & 185.3 & 152.1 & 100.0 \\
\hline & $\operatorname{SE}(\mathbf{m}) \pm$ & 5.6 & 4.0 & 6.9 & 5.1 & 11.4 & 6.5 & 13.3 & 8.0 \\
\hline & $\mathrm{CD}(\mathrm{P}=0.05)$ & 16.5 & 11.8 & 20.4 & 15.2 & 33.8 & 19.3 & 39.9 & 23.3 \\
\hline
\end{tabular}


Table.3 Effect of various sources of zinc on dehydrogenase activity in soil ( $\mu \mathrm{g}$ of TPF $\mathrm{g} \mathrm{soil}^{-1}$ Day $^{-1}$ )

\begin{tabular}{|c|c|c|c|c|c|}
\hline S. No & Treatment & $\begin{array}{l}\text { 30DAT } \\
\text { Tillering } \\
\text { stage }\end{array}$ & $\begin{array}{l}\text { 60DAT } \\
\text { Panicle } \\
\text { emergence stage }\end{array}$ & $\begin{array}{l}\text { 90DAT } \\
\text { Grain filling } \\
\text { stage }\end{array}$ & Harvest \\
\hline T1 & Control (no fertilizers were applied) & 30.2 & 50.0 & 36.0 & 30.2 \\
\hline T2 & $\begin{array}{l}\text { Recommended dose of } \mathrm{N}: \mathrm{P}_{2} \mathrm{O}_{5}: \mathrm{K}_{2} \mathrm{O} \\
\text { @120:60:40 Kg ha' }\end{array}$ & 56.9 & 80.0 & 67.7 & 50.7 \\
\hline T3 & $\begin{array}{l}\text { RDF +Soil application of } \mathrm{ZnSO4} \\
@ 25 \mathrm{Kg} \mathrm{ha}^{-1} \text { at transplanting }\end{array}$ & 81.9 & 134.3 & 104.1 & 80.8 \\
\hline T4 & $\begin{array}{l}\text { RDF + Soil application of nano zinc as } \\
\text { impregnated granules @10kg } \\
\text { ha }^{-1} \text { at transplanting }\end{array}$ & 60.2 & 88.6 & 72.2 & 57.2 \\
\hline T5 & $\begin{array}{l}\text { RDF + Soil application of nano zinc as } \\
\text { impregnated granules @15kg } \\
\text { ha }^{-1} \text { at transplanting }\end{array}$ & 65.1 & 91.2 & 83.6 & 60.1 \\
\hline T6 & $\begin{array}{l}\text { RDF + Soil application of bio zinc } \\
@ 15 \mathrm{~kg} \mathrm{ha}^{-1} \text { at transplanting }\end{array}$ & 76.8 & 122.0 & 99.2 & 70.2 \\
\hline T7 & $\begin{array}{l}\text { RDF + Soil application of bio zinc } \\
@ 30 \mathrm{~kg} \mathrm{ha}^{-1} \text { at transplanting. }\end{array}$ & 86.5 & 145.8 & 114.9 & 84.8 \\
\hline T8 & $\mathrm{RDF}+$ Foliar spray of $0.2 \%$ as $\mathrm{ZnSO}_{4}$ & 39.2 & 71.0 & 55.0 & 33.9 \\
\hline T9 & $\begin{array}{l}\text { RDF +Foliar spray of } 1 \mathrm{ml} \mathrm{I}^{-1} \text { as nano } \\
\text { zinc }\end{array}$ & 41.2 & 72.9 & 46.1 & 40.0 \\
\hline T10 & $\begin{array}{l}\text { RDF +Foliar spray of } 2 \mathrm{ml} \mathrm{I}^{-1} \text { as nano } \\
\text { zinc }\end{array}$ & 40.9 & 79.7 & 57.7 & 40.8 \\
\hline T11 & $\begin{array}{l}\text { RDF +Foliar spray of } 1.5 \mathrm{ml} \mathrm{I}^{-1} \text { as bio } \\
\text { zinc }\end{array}$ & 46.0 & 70.9 & 59.8 & 43.0 \\
\hline \multirow[t]{3}{*}{ T12 } & $\begin{array}{l}\text { RDF +Foliar spray of } 3 \mathrm{ml} \mathrm{l}^{-1} \text { as bio } \\
\text { zinc }\end{array}$ & 50.6 & 82.0 & 64.9 & 45.1 \\
\hline & $\mathrm{SE}(\mathbf{m}) \pm$ & 2.5 & 3.3 & 4.3 & 5.8 \\
\hline & $\mathrm{CD}(\mathrm{P}=\mathbf{0 . 0 5})$ & 7.6 & 10.0 & 12.8 & 17.3 \\
\hline
\end{tabular}

At 60 DAT stage there was a maximum increase in acid phosphatase activity and the treatment receiving $\mathrm{RDF}+$ Soil application of biozinc@30 kg ha ${ }^{-1}$ recorded the highest activity $\left(167.0 \mu \mathrm{g}\right.$ of $p$-nitrophenol $\mathrm{g}^{-1}$ soil $\mathrm{hr}^{-1}$ ). There was a gradual decrease seen in acid phosphatase activity at 90DAT and the treatment receiving RDF+ Soil application of biozinc@30 kg ha ${ }^{-1}(149.0 \mu \mathrm{g}$ of $p$-nitrophenol $\mathrm{g}^{-1}$ soil $\mathrm{hr}^{-1}$ ) recorded the highest acitivity and was on par with RDF+ Soil application of $\mathrm{ZnSO}_{4} @ 25 \mathrm{~kg} \mathrm{ha}^{-1}(130.9 \mu \mathrm{g}$ of $p$-nitrophenol $\mathrm{g}^{-1}$ soil hr ${ }^{-1}$ ).

At harvest there was a much decrease in acid phosphatase activity among all the treatments and the highest value was seen in RDF+ Soil application of bio zinc@30 kgha ${ }^{-1}(106.0 \mu \mathrm{g}$ of p-nitrophenol $\mathrm{g}^{-1}$ soil $\mathrm{hr}^{-1}$ ) which was on par with $\mathrm{RDF}+$ Soil application of $\mathrm{ZnSO}_{4} @ 25 \mathrm{~kg}$ $\mathrm{ha}^{-1}\left(98.8 \mu \mathrm{g}\right.$ of $p$-nitrophenol $\mathrm{g}^{-1}$ soil $\left.\mathrm{hr}^{-1}\right)$, RDF+ Soil application of bio zinc@15 kg $\mathrm{ha}^{-1}\left(96.8 \mu \mathrm{g}\right.$ of $p$-nitrophenol $\mathrm{g}^{-1}$ soil $\left.\mathrm{hr}^{-1}\right)$. The lowest was recorded in control $(65.9 \mu \mathrm{g}$ of $p$ nitrophenol $\mathrm{g}^{-1}$ soil $\mathrm{hr}^{-1}$ ) which was on par with $\mathrm{RDF}+$ foliar spray of $0.2 \% \mathrm{ZnSO}_{4}(65.9 \mu \mathrm{g}$ of $p$-nitrophenol $\mathrm{g}^{-1}$ soil).

\section{Alkaline phosphatase activity}

At maximum tillering the highest alkaline phosphatase activity was observed in the treatment receiving RDF+ Soil application of biozinc@30 kg ha-1 $(206.1 \mu \mathrm{g}$ of $p$-nitrophenol $\mathrm{g}^{-1}$ soil $\mathrm{hr}^{-1}$ ) which was on par with RDF+ Soil application of $\mathrm{ZnSO}_{4} @ 25 \mathrm{~kg} \mathrm{ha}^{-1}(190.0 \mu \mathrm{g}$ of $p$ - 
nitrophenol $\mathrm{g}^{-1}$ soil $\left.\mathrm{hr}^{-1}\right), \mathrm{RDF}+$ Soil application of bio zinc@15 kg ha ${ }^{-1}(187.4 \mu \mathrm{g}$ of $p$ nitrophenol $\mathrm{g}^{-1}$ soil $\left.\mathrm{hr}^{-1}\right), \mathrm{RDF}+$ Soil application of nano zinc@15 kg ha ${ }^{-1}(176.0 \mu \mathrm{g}$ of $p$ nitrophenol $\mathrm{g}^{-1}$ soil $\mathrm{hr}^{-1}$ ).

At panicle emergence stage there was a maximum increase in alkaline phosphatase activity and the treatment receiving RDF+ Soil application of biozinc@30 kg ha ${ }^{-1}$ recorded the highest activity $\left(245.0 \mu \mathrm{g}\right.$ of $p$-nitrophenol $\mathrm{g}^{-1}$ soil $\left.\mathrm{hr}^{-1}\right)$. This treatment was followed by RDF+ Soil application of $\mathrm{ZnSO}_{4} @ 25 \mathrm{~kg} \mathrm{ha}^{-1}(221.1 \mu \mathrm{g}$ of $p$-nitrophenol $\mathrm{g}^{-1}$ soil $\left.\mathrm{hr}^{-1}\right)$, RDF+ Soil application of bio zinc@ $15 \mathrm{~kg} \mathrm{ha}^{-1}(201.6 \mu \mathrm{g}$ of p-nitrophenol $\mathrm{g}^{-1}$ soil $\mathrm{hr}^{-1}$ ) which were on par with each other. The lowest activity was recorded in control $(151.0 \mu \mathrm{g}$ of $p$-nitrophenol $\mathrm{g}^{-1}$ soil $\left.\mathrm{hr}^{-1}\right)$. There was a gradual decrease seen in acid phosphatase activity at 90DAT.

At harvest there was a much decrease in alkaline phosphatase activity among all the treatments and the highest value was seen in RDF+ Soil application of bio zinc@30 kg ha ${ }^{-1}$ $\left(183.7 \mu \mathrm{g}\right.$ of $p$-nitrophenol $\mathrm{g}^{-1}$ soil $\mathrm{hr}^{-1}$ ) which was on par with RDF+ Soil application of

$\mathrm{ZnSO}_{4} @ 25 \mathrm{~kg} \mathrm{ha}^{-1}(178.0 \mu \mathrm{g}$ of $p$-nitrophenol $\mathrm{g}^{-1}$ soil $\mathrm{hr}^{-1}$ ), RDF+ Soil application of bio zinc@15 kg ha ${ }^{-1}$ (164.6 $\mu \mathrm{g}$ of $p$-nitrophenol g ${ }^{-1}$ soil $\left.\mathrm{hr}^{-1}\right)$. The lowest was recorded in control $\left(68.7 \mu \mathrm{g}\right.$ of $p$-nitrophenol $\mathrm{g}^{-1}$ soil $\left.\mathrm{hr}^{-1}\right)$.

\section{Dehydrogenase activity}

Dehydrogenase is considered as an indicator of overall microbial activity because it has intracellular activity in all living microbial cells and it is linked with microbial respiratory process. The dehydrogenase activity is commonly used as an indicator of biological activity in soils (Burns, 1978). Dehydrogenase enzyme is known to oxidize soil organic matter by transferring protons and electrons from substrates to acceptors. These processes are part of respiration pathways of soil microorganisms and closely related to the type of soil. The data on effect of sources of zinc on activity of dehydrogenase ( $\mu \mathrm{g}$ TPF produced $g$ soil $\mathrm{d}^{-1}$ ) is presented in Table 3.

At 30DAT the highest dehydrogenase activity was observed in the treatment receiving RDF+ Soil application of biozinc@30 kg ha-1 $(86.5 \mu \mathrm{g}$ TPF produced $g$ soil $\mathrm{d}^{-1}$ ) which was on par with RDF+ Soil application of $\mathrm{ZnSO}_{4} @ 25 \mathrm{~kg} \mathrm{ha}^{-1}$ $\left(81.9 \mu \mathrm{g}\right.$ TPF produced $\mathrm{g}$ soil $\mathrm{d}^{-1}$ ). These treatments were followed by $\mathrm{RDF}+$ Soil application of bio zinc@15 kg ha ${ }^{-1}(76.8 \mu \mathrm{g}$ TPF produced $g$ soil $\left.\mathrm{d}^{-1}\right)$. The lowest dehydrogenase activity was observed in control $\left(30.2 \mu \mathrm{g}\right.$ TPF produced $\mathrm{g}$ soil $\left.\mathrm{d}^{-1}\right)$ which was on par with $\mathrm{RDF}+$ foliar application of $0.2 \%$ $\mathrm{ZnSO}_{4}$ spray (39.2 $\mu \mathrm{g}$ TPF produced g soil d $\left.{ }^{-1}\right)$.

At 60DAT there was a maximum increase in dehydrogenase activity and the treatment receiving RDF+ Soil application of biozinc@30 $\mathrm{kg} \mathrm{ha}^{-1}$ recorded the highest activity $(145.8 \mu \mathrm{g}$ TPF produced $g$ soil $\mathrm{d}^{-1}$ ).

There was a gradual decrease in dehydrogense activity at 90DAT and the treatment receiving RDF+ Soil application of biozinc@30 kg ha ${ }^{-1}$ (114.9 $\mu \mathrm{g}$ TPF produced $\mathrm{g}$ soil $\mathrm{d}^{-1}$ ) recorded the highest activity and was on par with RDF+ Soil application of $\mathrm{ZnSO}_{4} @ 25 \mathrm{~kg} \mathrm{ha}^{-1}(104.1 \mu \mathrm{g}$ TPF produced g soil $\mathrm{d}^{-1}$ ).

At harvest there was a much decrease in dehydrogenase activity among all the treatments and the highest value was seen in RDF+ Soil application of bio zinc@30 $\mathrm{kgha}^{-1}(84.8 \mu \mathrm{g}$ TPF produced $\mathrm{g}$ soil $\mathrm{d}^{-1}$ ) which was on par with RDF+ Soil application of $\mathrm{ZnSO}_{4} @ 25 \mathrm{~kg}$ ha ${ }^{1}\left(80.8 \mu \mathrm{g}\right.$ TPF produced g soil d $\left.{ }^{-1}\right), \mathrm{RDF}+$ Soil application of bio zinc@ $15 \mathrm{~kg} \mathrm{ha}^{-1}(70.2 \mu \mathrm{g}$ TPF produced $g$ soil $\left.\mathrm{d}^{-1}\right)$. The lowest was recorded in control $(30.2 \mu \mathrm{g}$ TPF produced $\mathrm{g}$ soil $\mathrm{d}^{-1}$ ). Similar to urease and phosphatase the dehydrogenase activity increased with the age of the crop and attained maximum at 60 DAT and decreased at harvest. Similar results were also reported by Rai and Yadav (2011). The increase in dehydrogense activity was attributed due to increase in population of anaerobic microorganism in submerged soils. There was a 
shift in soil micro flora from aerobic of facultative and obligatory anaerobic ones after the soil is flooded. The shift from aerobic to anaerobic microorganism was found to increase the dehydrogenase activity.

It has been observed that the treatment receiving the soil application of biozinc@30 kg ha ${ }^{-1}$ have lead to an increased activity of enzymes. Addition of trace metals like zinc to soil may influence microbial proliferation and enzyme activity possibly leading to an increase in rates of biochemical process in the soil environment. However when application of abnormally higher concentration rate they could cause an increase in inhibition of enzyme activity. It has been observed that trace elements as activation of enzyme in soil varies with the soil, the concentration and the form of added trace element on the enzyme assay.

\section{References}

Burns, R.G. 1978. Enzyme activity in soils, some theoritical and practical modifications. In Soil Enzymes. (Burns RG, ed.). Acadamic press, London. Pp. 295-340.

Casida, L.E. J.R., Klein, D.A and Santaro, T. 1964. Soil dehydrogenase activity. Soil Science. 96: 371-376.

DeRosa, M.C., Monreal, C., Schnitzer, M., Walsh, R and Sultan, Y. 2010. Nanotechnology in fertilizers. Nature nanotechnology. 32(5): 1234-1237.

Giraldo, J.P., Landry, M.P., Faltermeier, S.M., Nicholas, T.P., Iverson, N.M., Boghossian, A.A., Reuel, N.F., Hilmer, A.J., Sen, F., Brew, J.A., Strano, M.S. 2014. Plant nanobionics approach to augment photosynthesis and biochemical sensing. Nature Material.

INDIA STAT. 2015-16. India's Comprehensive
Statistical Analysis. (http://www.india stat.com).

Maret W 2009. Molecular aspects of human cellular zinc homeostasis: redox control of zinc potentials and zinc signals. Biometals. 22: 149-157.

Muthukumararaja T, Sriramachandrasekharan MV 2012. Critical limit of zinc for rice soils of veeranam command area, Tamilnadu, India. ARPN J Agric Biol Sci., 7(1): 23-34.

Nair, R., Varghese, S.H., Nair, B.G., Maekawa, T., Yoshida, Y., Kumar, D.S. 2010. Nanoparticulate material delivery to plants. Journal on Plant Science. 179:154-163.

Panse, V.G and Sukhatme, P.V. 1978. Statistical methods for agricultural works. Indian council of Agricultural Research, New Delhi. Pp. 361.

Rai, T.N and Yadav, J. 2011. Influence of inorganic and organic nutrient sources on soil enzyme activities. Journal of the Indian society of Soil Science. 59(1): $54-59$.

Ramalakshmi, Ch. S. 2011.Vermicomposting for effective waste management and its evaluation under INM rice - pulse cropping system. M.Sc. (Ag.) Thesis. Acharya N. G. Ranga Agricultural University, Rajendranagar, Hyderabad.

Senthilkumar, S. 2000. Integrated plant nutrient supply system in hybrid rice. M.Sc. (Ag.) thesis. Acharya N.G. Ranga Agriculutral University, Rajendranagar, Hyderabad.

Speir, J.W. and Ross, D.J. 1978. Soil Phosphatase and Sulphatase. In R.G. Burns (ed.) - Soil Enzymes, Academic Press Inc., New York.

Tabatabai, M.A and Bremner, J.M. 1969. Use of p-nitrophenyl phosphate for assay of soil phosphatase activity. Soil Biology and Biochemistry.1: 301-307.

Tabatabai, M.A and Bremner, J.M. 1972. Assay of urease activity in soils. Soil Biology and Biochemistry, 4: 479-489.

\section{How to cite this article:}

Apoorva, M.R., P. Chandrasekhar Rao, G. Padmaja and Subhash Reddy, R. 2018. Activity of Soil Urease, Phosphatase and Dehydrogenase as Influenced by Various Sources of Zinc in Rice (Oryza sativa L.). Int.J.Curr.Microbiol.App.Sci. 7(01): 2640-2647.

doi: https://doi.org/10.20546/ijcmas.2018.701.315 